Anja Schmidt

\title{
Human Trafficking - Between Punishable Human Rights Violations and Decriminalization
}

\section{Abstract}

The necessity of combating human trafficking is often justified by the violation of human rights of the victims of human trafficking. Criticism has, however, repeatedly been voiced that the victim-centred, human rights-based approach has not been consistently applied - because, in reality, state interests in effectively combating (organized) crime and securing borders against illegal migration take precedence. An opposite tendency criticizes the criminalization of human traffic on the grounds that human rights are not violated in every case within the definition of human trafficking, and criminalization is inappropriate in such cases. Furthermore, various parties point out that there is little empirical data on trafficking in human beings, and the available data is unreliable. This contribution aims to provide an overview of these issues and argue in favour of a nuanced examination of phenomena covered by the legal definition of human trafficking.

\section{Introduction}

The necessity of combating human trafficking is often justified by the violation of human rights of the victims of human trafficking. For example, the preamble of the Council of Europe Convention on Action against Trafficking in Human Beings ${ }^{1}$ states that "trafficking in human beings constitutes a violation of human rights and an offence to the dignity and the integrity of the human being"; According to Art. 1 para. 1 lit. a, b, the purposes of the Convention are "to prevent and combat trafficking in human beings, while guaranteeing gender equality" and "to protect the human rights of the victims of trafficking, design a comprehensive framework for the protection and assistance of victims and witnesses, while guaranteeing gender equality, as well as to

* Dr. Anja Schmidt, Principal researcher for the DFG funded research project "pornography and sexual self-determination" at the Martin Luther University of Halle-Wittenberg, affiliated to the Chair for criminal law, legal philosophy/legal theory of Prof. Dr. Joachim Renzikowski. This article is a translated contribution published in German in K. Höffler (ed.), Criminal Law Discourse of the Interconnected Society, Nomos, Baden-Baden, p. 287 et seq.

1 Council of Europe Treaty 16.5.2005, SEV Nr.197. 
ensure effective investigation and prosecution”. In the recitals for the Directive $2011 / 36 / \mathrm{EU}^{2}$ it is stated that "[ $\mathrm{t}$ ]rafficking in human beings is a serious crime, often committed within the framework of organised crime, a gross violation of fundamental rights $[\ldots]$ ”.

Criticism has, however, repeatedly been voiced that the victim-centred, human rights-based approach has not been consistently applied - because, in reality, state interests in effectively combating (organized) crime and securing borders against illegal migration take precedence. ${ }^{3}$ An opposite tendency criticizes the criminalization of human traffic on the grounds that human rights are not violated in every case within the definition of human trafficking, and criminalization is inappropriate in such cases. ${ }^{4}$ Furthermore, various parties point out that there is little empirical data on trafficking in human beings, and the available data is unreliable. ${ }^{5}$

This contribution aims to provide an overview of these issues and argue in favour of a nuanced examination of phenomena covered by the legal definition of human trafficking. To begin with, the paper describes what constitutes human trafficking as a violation of human rights (2). This is contrasted with the range of phenomena covered by the legal definition of human trafficking. In the process, an approach is discussed which aims to establish more precision in these definitions (3). Then the paper explains how little we know about the forms and extent of human trafficking or other phenomena that are understood as such (4). It is pointed out that the unsubstantiated empirical basis means that human trafficking can be instrumentalized politically and ideologically, and how this is done at the expense of those who suffer human rights violations as a result of human trafficking (5). Finally, the paper argues in favour of a differentiated consideration of the human trafficking phenomenon based on the criterion of human rights violations which neither exaggerates all phenomena that have so far been legally defined as human trafficking as human rights violations, nor trivialises human rights

2 OJ $2011 \mathrm{~L}$ 101/1.

3 See B. Uhl, Die Sicherheit der Menschenrechte, 2014, p. 209 et seq.; C. Köbler, Opferschutz im Bereich des Menschenhandels, 2016, p. 53 et seq.; J. Renzikorwski, Menschenhandel als Menschenrechtsverletzung - und was daraus folgt, in: K. Kappler/V. Vogt (eds.), Gender im Völkerrecht, Konfliktlagen und Errungenschaften, 2019, p. 84 et seq.

4 See T. Hörnle, Die internationale Bewegung gegen Menschenhandel - einige kritische Überlegungen, in: Festschrift für Urs Kindhäuser, 2019, p. 675 et seq., p. 681; See the following contributions in R. Haverkamp/E. Herlin-Karnell/C. Lernestedt (eds.), What is Wrong with Human Trafficking? 2019: T. Hörnle, Human Trafficking. Human Rights Activism and its Consequences for Criminal Law, p. 119 et seq.; V. Bergelson, Vulnerability, Exploitation and Choice, p. 193 et seq.; C. Lernestedt, What Does the Trafficker Do Wrong and Towards What or Whom?, p. 137 et seq.; P. H. van Kempen/S. Lestrade, Limiting the Criminalisation of Human Trafficking, p. 217 et seq.

5 See C. Lindner, Die Effektivität transnationaler Maßnahmen gegen Menschenhandel in Europa, 2014, p. 26 et seq.; H.-J. Albrecht, Measuring Human Trafficking, in: Haverkamp/ Herlin-Karnell/Lernestedt (eds.), What is Wrong with Human Trafficking?, p. 37; $R$. Haverkamp, in: Haverkamp/Herlin-Karnell/Lernestedt (eds.), What is Wrong with Human Trafficking?, p. 62 et seq. 
violations caused by human trafficking and subordinates them to security policy interests (6) This article does not consider human trafficking at the expense of minors.

\section{Human trafficking as a human rights violation?}

The reason that human trafficking violates the human rights of victims is that trafficking in human beings impairs their freedom to such an extent that they become reified or commodified. ${ }^{6}$

Article 5 III CFR, accordingly, expressly prohibits human trafficking. Article 4 UDHR prohibits holding people in slavery and servitude; Article 23 UDHR guarantees the right to work under just and favourable conditions. Article 8 ICCPR and Article 4 ECHR prohibit slavery, servitude and forced or compulsory labour. The ECtHR has ruled that trafficking in human beings is covered by Article 4 ECHR, even though it is not explicitly mentioned there. After all, there is no doubt that human trafficking threatens human dignity and the human rights of the victims. Human trafficking is based on the exercise of power, as it is connected with the right to property. Human trafficking means that people are bought and sold as commodities, forced to work for little or no pay, often in the sex industry but also elsewhere. ${ }^{7}$

There are cases of human trafficking where it is immediately obvious that there are serious violations of human rights. The phenomena covered by the term human trafficking are, however, complex and diverse, differing, inter alia, in the nature and seriousness of the violation of the rights of the victims. There are, therefore, voices that assume that not every case of human trafficking constitutes a serious violation of human rights, or indeed any violation of human rights at all.

\section{Forms and characteristics of buman trafficking}

The law covers very different forms of exploitation in its definition of human trafficking, while the actual phenomena described as human trafficking are also very diverse.

\section{The scope of legal definitions of human trafficking}

The legal definitions of trafficking in human beings cover a wide range of acts, instruments of crime and forms of exploitation.

The protocol to prevent, suppress and punish trafficking in persons, especially women and children, supplementary to the UN Convention against Transnational Or-

6 See Renzikowski (fn. 3), p. 74 et seq.; P. Follmar-Otto, Menschenhandel in Deutschland, in: DIMR (ed.), 2009, p. 31 et seq.; ECHR, Rantsev v. Cyprus and Russia, Application no. 25965/04, Judgement 7 January 2010, margin no 197.

7 See ECHR, Rantsev v. Cyprus and Russia (fn. 6), margin no 272 et seq., esp. 281 et seq.; detailed information on human rights guarantees in human trafficking: Köbler (fn. 3), p. 55 et seq., Follmar-Otto (fn. 6), p. 30 et seq. 
ganised Crime adopted on 15 November 2000, known as the Palermo Convention, ${ }^{8}$ defines in its Article 3 lit. a, b human trafficking as "the recruitment, transportation, transfer, harbouring or receipt of persons, by means of the threat or use of force or other forms of coercion, of abduction, of fraud, of deception, of the abuse of power or of a position of vulnerability or of the giving or receiving of payments or benefits to achieve the consent of a person having control over another person, for the purpose of exploitation", even if the trafficked person has consented in the exploitation. Thus, certain actions such as recruitment and promotion, which in themselves are neutral, are necessary for a crime to have occurred. They are punishable because they are committed for a specific purpose by means such as violence or deception. The purpose of the action in the crime are the variety of forms of exploitation specified in the Palermo Convention as including at least the exploitation of the prostitution of others or other forms of sexual exploitation, forced provision of labour or services, slavery or practices similar to slavery, servitude or the forced removal of organs. Art 4 of the Council of Europe Convention on Action against Trafficking in Human Beings of 16 May 20059 adopts the definition of the Palermo Convention.

The definition of human trafficking in Article 2 of Directive 2011/36/EU of the European Parliament and of the Council of 5 April 2011 on preventing and combating trafficking in human beings and protecting its victims and replacing Council Framework Decision 2002/629/JHA ${ }^{10}$ is closely based on the definition of the Palermo Convention. The Directive refines the definition of human trafficking, in particular by including forced begging in the definition of forced labour or services, and adds the exploitation of criminal activities to the purpose of the action in the crime. ${ }^{11}$

In Germany, Directive 2011/36/EU was implemented by the Act to Improve the Fight against Human Trafficking and to Amend the Federal Central Register Law as well as the Eighth Book of the Social Code of 11 October 2016. ${ }^{12} \$ 232$ I 1 of the German Criminal Code ("StGB") lists the recruitment, transportation, transfer, harbouring or reception of persons as actions punishable by law. According to $\$ 232$ I $1 \mathrm{StGB}$, the means of action are the taking advantage of personal or economic predicament or of helplessness on account of being in a foreign country. Therefore, the basic offence can be committed without the use of coercive force. Use of force, threat of serious harm, deception, the abduction or gaining of physical control over a person as a means of action lead to the application of the statute in $\$ 232$ II StGB concerned with serious human trafficking. ${ }^{13} \$ 232$ I 1 no. $1-3$ StGB lists as the purposes of the action exploita-

8 United Nations, Treaty Series, vol. 2237, p. 319; Doc. A/55/383; BGBl III 29.12.2005 Nr. 220.

9 Council of Europe, Treaty Series, No. 197.

10 OJ 2011 L 101/01.

11 See in detail Lindner (fn. 5), p. 18.

12 Gesetz zur Verbesserung der Bekämpfung des Menschenhandels und zur Änderung des Bundeszentralregistergesetzes sowie des Achten Buches Sozialgesetzbuch BGBl.2016 I, 2226.

13 See for questions if this meets the requirements of the Directive 2011/36/EU, MüKo-StGB/ Renzikorwski $\$ 232$ mn. p. 33. 
tion by coercive prostitution, the forced performance or tolerance of sexual acts, exploitation by employment, by forced begging or commission criminal offences, slavery or similar conditions as well as the unlawful removal of organs.

The ways in which exploitation is considered to be human trafficking are, therefore, very varied. This also applies to the means of action, which range from coercion, fraud/deception and abduction to the exploitation of a particular helplessness. The German provision adds to this the exploitation of personal or economic predicament.

\section{The scope of real cases}

The legal definitions of human trafficking cover a wide variety of situations in which the law is violated in varying degrees of severity. In the context of this paper, this will be illustrated using examples of labour exploitation and exploitation by coercive prostitution. ${ }^{14}$

\section{a) Exploitation of labour}

In advisory practice cases of human trafficking for labour exploitation are documented which range from employment relationships where exploitative conditions are enforced by force, threat or deception, to openly consensual relationships with criminally relevant exploitation, to openly consensual employment relationships on unfavourable terms. ${ }^{15}$

Openly coerced employment relationships exist, for example, when persons employed by embassy staff of their home country are forced to work like slaves in a foreign country under poor conditions. One documented case is that of a Filipino employee in a diplomat's household who was isolated from the outside world. Even though her suitcase had been lost on the journey, she was provided with house clothes only and no means of personal hygiene. She worked almost all day in the household and did not receive the previously agreed pay. The victim here was probably exploited

14 For cases involving the exploitation of begging or criminal activities of others see Lindner (fn. 5), p. 42 et seq.; Bundeskriminalamt, Menschenhandel und Ausbeutung. Bundeslagebild, 2019, p. 23 et seq.; for cases involving illegal organ removal see Trafficking in organs, tissues and cells and trafficking in human beings for the purpose of the removal of organs, in: Council of Europe/United Nations, 2009; for murder for the purpose of organ removal see Inhuman treatment of people and illicit trafficking in human organs in Kosovo, in: Council of Europe/Marty, 2011, Dok. $12462 \mathrm{mn} .29$ et seq.

15 See N. Cyrus/D. Vogel/K. de Boer, Menschenhandel zum Zweck der Arbeitsausbeutung, 2010, p. 59 et seq.; see also MüKo-StGB/Renzikowski $\$ 232 \mathrm{mn} .13$ et seq.; J. Renzikowski, Contemporary Problems of Labour Exploitation, in: E. Hilgendorf/J.-C. Marschelke/K. Sekora, 2015, p. 117 et seq.; N. Cyrus/K. de Boer, Darstellung und Analyse der Vorkommensweise des Menschenhandels zur Arbeitsausbeutung, in: Internationale Organisation für Migration (IOM), 2011, p. 47 et seq. 
by dint of her helplessness in a foreign country as well as being deprived of liberty and subjected at least to psychological pressure. ${ }^{16}$

The following case concerns an employment relationship under exploitative conditions brought about by deception, in which the employer also took advantage of the victim's inexperience and helplessness in a foreign country. ${ }^{17}$ As she had previously worked as a cook in Ethiopia, the victim's employer's brother offered the woman a well-paid job as a chef in Berlin. She entered Germany legally. However, at beginning of her employment, she was told that she would have to work for a year without pay to cover the cost of her entry into Germany. She worked for 19 hours a day, including weekends. When she became ill after one year, she was hospitalized. After being discharged from the hospital, her employer informed her that she now had to work to pay the hospital bill. She did not know that she had health insurance. She understood at that moment, however, that she would never be able to work for this employer without incurring debts. After 18 months, she managed to escape with the help of a regular customer. During the entire time, she had received a total of 500 EUR in wages. ${ }^{18}$

The next case is about a consensual employment relationship under exploitative conditions, which, however, was beneficial for all parties involved: A woman from another country came to Germany illegally to care for a bedridden woman who spoke the same language. She lived in the patient's household and looked after her around the clock. Her wages were 400 EUR per month. Although she considered the wage to be very low, she was able to earn at least some money in Germany, while she could neither find work nor receive a pension in her home country. The expert who reported this case in a study on human trafficking for the purpose of labour exploitation assumed that there are networks that organise illegal entry into Germany and arrange contact with persons in need of care. ${ }^{19}$ An openly consensual employment relationship on unfavourable terms would exist if the woman had received $60 \%$ of the remuneration customary in Germany for her services.

The cases differ in the nature and seriousness of the infringement of legal rights. In the first two cases, the right to self-determination is infringed in different ways - by coercion or by deception. In the third and fourth cases, on the other hand, the victim and the perpetrator reach a mutually beneficial decision on working conditions that, when they are measured against German social and economic condition, are exploitative or unfavourable.

16 See Cyrus/Vogel/de Boer (fn. 15), p. 56 et seq., p. 61 et seq.

17 See Cyrus/Vogel/de Boer (fn. 15), p. 60 et seq.

18 See Cyrus/Vogel/de Boer (fn. 15), p. 51 et seq.

19 See Cyrus/Vogel/de Boer (fn. 15), p. 50 et seq., p. 59 et seq. 
b) Exploitation with disregard for sexual self-determination

A similar differentiation can be made in the area of exploitation through prostitution, which however requires a fundamental distinction to be made between forced prostitution and voluntary prostitution.

An exploitative relationship, which was intended to be brought about by deception, threats and violence, occurred in the following case, which was brought before the Asylum Court of the Republic of Austria. ${ }^{20}$ A young woman from Nigeria entered Austria illegally on the advice of a friend of the family, after the latter had assured her that she could earn good money in Europe and would not have to work in prostitution. She was instructed by traffickers to register as an asylum seeker under a false pretext. She was picked up from the initial reception centre by a woman and taken to Vienna, where she was instructed to work as a prostitute to cover the costs of her journey. She escaped twice with the help of a non-governmental organisation, but each time she was found by the traffickers, beaten and threatened with death if she refused to work as a prostitute. She was also warned that if she refused, her relatives in Nigeria would be harmed. Indeed, her siblings were arrested in Nigeria at the instigation of the human trafficking ring, her grandfather's house was destroyed and her brother was shot and wounded. This case represents a serious violation of human rights because of the trafficking of human beings for exploitation through forced prostitution. Forced prostitution constitutes a serious violation of the right to sexual self-determination and thus of human dignity.

The situation is different in cases where someone voluntarily legally or illegally enters a wealthier country in order to earn money by prostitution. ${ }^{21}$ There are conceivable cases in which the working conditions are mutually agreed upon for mutual benefit, even if they are exploitative. It is also possible, however, that there may be deceptive practices that misrepresent the true working conditions, such as paying a lower wage or demanding different practices than agreed upon. In the first case, a violation of the right to sexual self-determination could be argued on the grounds that a person has an objectively determined dignity, which is always violated in the case of the sale of sexual services. However, this position is questionable because it separates the concept of dignity from that of self-determination. ${ }^{22}$ That an injustice is worthy of punishment can only be grounded in the fact that a person earns money by commercializing the sexuality of another person - a highly personal legal right. What is then protected is the sexual and economic self-determination of prostitutes with regard to the choice of

20 See Asylgerichtshof der Republik Österreich, Erk. v. 14.5.2009, Spruch C15 263.728 0/2008/25E.

21 See J. R. Henning, Jenseits von Menschenhandel und Zwangsprostitution, in: P. Thiee (ed.), Menschen Handel. Wie der Sexmarkt strafrechtlich reguliert wird, 2008, p. 172 et seq.

22 See A. Schmidt, Die Reform der Regulierung der freiwilligen Prostitution, Kritische Justiz (KJ) 2015, p. 162 et seq. 
their sexual contacts. ${ }^{23}$ Others, however, assume that in cases where there is only deception about working conditions, a punishable violation of rights does not exist. ${ }^{24}$ However, if a person is deceived about working conditions, not only is money made from the sexuality of that person, but deception is also used to manipulate the person's decision-making process, which constitutes a punishable offence.

\section{Criticism}

The breadth of legal definitions is criticised in various ways. In the following, criticism of the means of action in exploiting a helpless situation, or of taking advantage of a personal or economic predicament, and the fact that the victim's consent does not have to be absent, is singled out as fundamental points of criticism of the regulation of human trafficking.

This means of action is the common denominator in cases in which people leave their familiar surroundings on their own initiative in order to subject themselves to exploitation because it is beneficial to them. An example is the nursing care case mentioned above. In this kind of case, the economic predicament of the victims is instrumentalised to bring them to the country of destination in order for them to be exploited there, which according to the law constitutes human trafficking. There is, however, no violation of the right to self-determination in such a case in so far as the person entered the country voluntarily and with full knowledge of his or her working conditions and started to work. Although this person is exploited according to conditions in the country of destination, the situation is nonetheless to his or her advantage, since he or she earns money in the first place and also earns more money than he or she could earn by working in a comparable job in his or her country of origin. Here, traffickers and victims act consensually and to their mutual benefit. ${ }^{25}$ In such cases, the migrants also often do not consider themselves victims of human trafficking, but simply expect to be paid their hard-earned wages. ${ }^{26}$ These situations are, therefore, not considered to be criminal human trafficking as there is no violation of the victim's right to self-determination and his or her dignity. Rather, it is a matter of protecting other legal interests, such as protecting the borders of the destination country or the external borders of the $\mathrm{EU}$, and protecting the economic and social conditions in the destination country from illegal labour migration. ${ }^{27}$

23 See for reasons for punishment in relation to the exploitation of prostitutes and procuring MüKo-StGB/Renzikowski $\$ 180 \mathrm{a}$ mn. 1, $\$ 181 \mathrm{a} \mathrm{mn}$. 1; Sch/Sch/Eisele $\$ 180 \mathrm{a} \mathrm{mn}$. 1, 181a Rn. 1; Fischer StGB $\ 180$ a mn. 3, \$181a mn. 2.

24 See Bergelson, (fn. 4), p. 198.

25 See van Kempen/Lestrade (fn. 4), p. 233 et seq.

26 See Renzikowski (fn. 3), p. 75 et seq.

27 See van Kempen/Lestrade (fn. 4), p. 233 et seq.; see also Bergelson (fn. 4), p. 204 et seq.; Hörnle (fn. 4), p. 675 et seq.; Hörnle (fn. 4), p. 119, p. 129 et seq.; Renzikoreski (fn. 3), p. 76; Lernestedt (fn. 4), p. 140. 
In principle, this can be agreed with, but the argumentation is debatable in cases where there is an extreme imbalance between the wages customary in the destination country and the wages actually agreed and paid. An example of this is the case described above from the nursing sector, in which the carer worked almost around the clock every day and received only 400 EUR per month..$^{28}$ In such situations, a person is exploited due to their economic predicament and their opportunities for self-determination being considerably restricted. Although the degree of injustice in such cases is lower than in cases in which violence or threats are used, the severe exploitation of a predicament that considerably limits the person's self-determination legitimises its criminalization. This is because, although there is no serious violation of human rights that would constitute a violation of human dignity as there is in cases of violence or threat, nonetheless the right to self-determination is violated due to the extreme imbalance of power that the exploiting person abuses. ${ }^{29}$

It is also questionable whether in cases of prostitution and illegal organ removal, a human rights violation can be dismissed on grounds that the person who prostitutes themselves or donates an organ has voluntarily accepted prostitution or organ donation due to an economic or social predicament. ${ }^{30}$ This is because these persons have a highly personal legal right - to sexual self-determination or physical integrity with regard to an organ - which no third person should be able to profit from by taking advantage of a predicament.

The individual situations of the cases that are covered by the legal definitions of human trafficking must, therefore, be analysed in a differentiated manner to determine whether and to what extent human rights are violated in them. Only if this is the case, is criminalization justified. A severe violation of human rights occurs when the right to self-determination has been violated by deception, violence, the threat of a serious harm or a form of deprivation of liberty and the victim is exploited. However, a violation of human rights, albeit less severe, also occurs when the victim acts voluntarily but they are manipulated on the basis of their predicament and the victim is exploited to a considerable extent, or when the victim is exploited in prostitution or through unlawful organ donation.

\section{Unsubstantiated empirical basis}

Human trafficking phenomena are known mainly through cases documented from consultation practice, police investigations and court decisions. However, it is completely unclear how widespread human trafficking actually is and who is affected by it

28 The case was reported in 2010 but even at this time, the usual renumeration would have been significantly higher as well.

29 See for this differentiation MüKo-StGB/Renzikorwski $\$ 232 \mathrm{mn}$. 16; see also V. E. Munro, Über Rechte und Rhetorik: Diskurse um Erniedrigung und Ausbeutung im Kontext von Sexhandel, Kritische Justiz (KJ) 2009, p. 370 et seq., p. 378 et seq.

30 See in contrast Bergelson (fn. 4), p. 207 et seq.; without this restriction also Hörnle (fn. 4), p. 680 et seq. 
in its various forms. With regard to empirically backed knowledge on human trafficking, one can, as Lindner puts it, speak of a "crisis in knowledge" rather than a state of knowledge. ${ }^{31}$

\section{Situation report on trafficking in human beings by the BKA}

The statistics on human trafficking in Germany, which are pooled annually through the German Federal Office of Criminal Investigations [BKA] Situation Report on $\mathrm{Hu}-$ man Trafficking, show very low levels. In the last five years, the number of investigations conducted and concluded by the police in human trafficking for the purpose of sexual exploitation where the crime was committed in Germany ranges between 327 (2017) and 392 (2014) cases; in the field of labour exploitation, 11 investigations were concluded in 2014 and 2017, and 21 in 2018.32 With regard to exploitation through begging, two cases were concluded by the police in 2018; police also completed seven investigations involving exploitation through commission of criminal offences in the same period. ${ }^{33}$ Cases of human trafficking for the purpose of illegal organ removal were not reported. ${ }^{34}$

These figures are empirically backed in that they are well-defined in terms of geography and factual aspects, and their origin and the method of data collection are clearly identifiable. ${ }^{35}$ However, they depict only the known proportion of crimes actually reported to the police. Which cases enter the statistics also depends on the work carried out by the police, for example, on the resources used and the phenomena identified as human trafficking by the investigating officers. Therefore, the statistics reveal more about the work of the police itself - about the events that have been identified and defined as human trafficking - and less about the phenomenon of human trafficking. ${ }^{36}$ The fact that there have been no police investigations into human trafficking for the purpose of illegal removal of organs does not necessarily mean that there are no cases of it happening. The fact that there are significantly fewer investigations into the exploitation of labour than into sexual exploitation means only that the police have investigated more cases in the area of sexual exploitation.

There are no reliable estimates of the real extent of human trafficking in Germany, ${ }^{37}$ and it is also difficult to find a basis for making estimates. ${ }^{38}$ Specialist counselling centres also handle cases that do not lead to a police investigation or the conclusion of an

31 See Lindner, (fn. 5), p. 26 [dt: Wissensnotstand].

32 See $B K A$ (fn. 14), p. 4, p. 19.

33 See $B K A$ (fn. 14), p. 23 et seq.

34 See $B K A$ (fn.14), p. 26.

35 See Lindner (fn. 5), p. 31 et seq.

36 See Albrecht (fn. 5), p. 41, p. 43 et seq.

37 See DIMR, https://www.institut-fuer-menschenrechte.de/themen/menschenhandel/basisinf ormationen-zu-menschenhandel/wie-viele-menschen-sind-in-deutschland-von-menschenha ndel-betroffen/ (29.10.2019). Cyrus/Vogel/de Boer (fn. 15), p. 10.

38 See Albrecht (fn. 5), p. 41, p. 44. 
investigation. Moreover, it is unlikely that all cases of human trafficking come to light at all. ${ }^{39} \mathrm{In}$ addition, there are indications that human trafficking investigations are not started or are discontinued due to the complexity of the facts of the case, due to the victims' reluctance to cooperate or, in cases with a cross-border dimension, due to a lack of cooperation from foreign authorities. ${ }^{40}$

\section{Data collection in the European Union}

The European Commission collects data on human trafficking in the European Union. In the 2018 final report on the data collection on trafficking in human beings in the $\mathrm{EU}^{41}$, data from the EU Member States on human trafficking was compiled and presented using a broad range of indicators. The report is based on a questionnaire that each Member State was asked to complete, although not all Member States answered all questions. The data is based on statistical surveys conducted by each Member State. All the data collected shows presumed victims of human trafficking or persons who have been formally identified as victims of human trafficking. ${ }^{42}$ However, data collection in the Member States is not conducted on the basis of uniform standards. For example, Germany only collects data from police crime statistics, while in the Netherlands data is also compiled by non-governmental organisations, welfare authorities and other actors. Furthermore, there are differences in national standards regarding criminal laws concerning human trafficking. This means that the data is not comparable. ${ }^{43}$ Its validity, i.e. the informative value with regard to what it measures,${ }^{44}$ is limited, as explained above in connection with the Federal Situation Report on Human Trafficking published by the BKA.

For 2015, 9147 and in 201611385 victims of human trafficking were recorded by this survey. The most frequent cases involved sexual exploitation (56\%), followed by labour exploitation ( $26 \%$ ); other forms of trafficking accounted for $18 \%$ of cases..$^{45}$

\section{Global estimates}

Regarding the worldwide prevalence of human trafficking, only estimates exist. The International Labour Organisation (ILO), for example, estimated that 40.3 million people worldwide were victims of modern slavery in 2016, with an estimated 24.9 mil-

39 See $K O K$, https://www.kok-gegen-menschenhandel.de/menschenhandel/daten-zahlen-fakte n/ (29.10.2019). Cyrus/Vogel/de Boer (fn. 15), p. 93.

40 See Lindner (fn. 5), p. 38; Cyrus/Vogel/de Boer (fn. 15), p. 94.

41 European Commission/Lancaster University, Data collection on trafficking in human beings in the EU, 2018.

42 See European Commission/Lancaster University (fn. 41), p. 12 et seq.

43 See Albrecht (fn. 5), p. 40.

44 See Albrecht (fn. 5), p. 39.

45 See European Commission/Lancaster University (fn. 41), p. 13 et seq. 
lion victims of forced labour and 15.4 million living in forced marriages. ${ }^{46}$ These estimates are based on national surveys in more than 48 countries, which are based partly on information on identified victims and partly on estimates. ${ }^{47}$ Although the data is thus linked back to specific sources, their reliability, comparability and validity are highly questionable. ${ }^{48}$

\section{Conclusions}

To conclude that human trafficking is unproblematic in terms of violations of rights and in terms of its extent just because the data available is limited and the number of investigations is limited would be wrong. As has been shown above in specific cases, human trafficking entails human rights violations of varying degrees of severity, even if these are not present in every case considered to be human trafficking under the law. We simply do not know the full extent of human trafficking and whether it, in fact, involves additional scenarios other than those we are aware of. As the matter stands, we can only state that the empirical basis for assessing the extent and forms of human trafficking is inadequate. As a result, it is also difficult to assess the necessity and effectiveness of measures to combat human trafficking. ${ }^{49}$ In order to better assess and effectively fight the various forms of human trafficking, it is necessary to gain more knowledge about the victims, the traffickers, their methods, the routes they take and the different forms of exploitation. ${ }^{50}$

Collecting data on trafficking in human beings is subject to many difficulties, ${ }^{51}$ as is the case with other crimes, and, therefore, it will not be possible to paint an entirely accurate picture. However, empirical studies and data collection will help to improve understanding of human trafficking. Article 5 (2) of the Council of Europe Convention on Action against Trafficking in Human Beings states that each Party shall establish effective policies or programmes to prevent trafficking in human beings, including by means of research. According to Article 9 (2) of the Palermo Convention, State Parties shall endeavour to undertake measures, including research, to prevent and combat trafficking in persons.

In order to collect and provide empirically sound data on the prevalence and forms of human trafficking in Germany, it is necessary to establish a National Rapporteur Unit in Germany, as provided for in Article 19 of Directive 2011/36/EU. This agency

46 See ILO, Global Estimates of Modern Slavery, 2017, p. 9 et seq.

47 See $I L O$ (fn. 46), p. 11 et seq.

48 See in detail for criticism on estimates Albrecht (fn. 5), p. 39, p. 42 et seq.; see also J. Goodey, Human Trafficking. Sketching Data and Policy Responses, Criminology and Criminal Justice 2008, p. 424 et seq.

49 See Lindner (fn. 5), p. 38 et seq.; H. Rabe, Wirksame Politik braucht verlässliche Daten, Deutsches Institut für Menschenrechte (DIMR) 2015, p. 2 et seq.

50 See IOM/BM.I Republic of Austria, Guidelines for the collection of data on trafficking in human beings, including comparable indicators 2009, p. 16.

51 See in detail Albrecht (fn. 5); see also Goodey (fn. 48), p. 424 et seq. 
would have the task of collecting statistical data on human trafficking in close cooperation with non-governmental organisations in order to measure the results of anti-trafficking actions. ${ }^{52}$ Additionally, the recommendation of the Council of Europe's Group of Experts on Trafficking in Human Beings (GRETA) must be implemented so that data can be collected from all stakeholders, including non-governmental organizations. ${ }^{53}$ The Member States of the European Union should collect the data in a standardised manner on the basis of the guidelines published by the International Organisation for Migration (IOM) in cooperation with the Austrian Federal Ministry of the Interior in 2009. These contain detailed recommendations for the coordinated collection of data by the Member States of the European Union in order to assess the real extent of human trafficking in the European Union. ${ }^{54}$

\section{Human trafficking as a construct capable of being instrumentalized}

On account of the limited available data, the discourse on human trafficking is very well-suited to instrumentalization both in a political and ideological sense. Goździak/ Bump, for example, remark "that the dominant anti-trafficking discourse is not evidence-based but grounded in the construction of particular mythology of trafficking" 55 . This criticism argues that the nature and extent of human trafficking, the identity of victims and perpetrators are constructed as phenomena in a way that fits the objectives of the respective stakeholders, but that these constructs have little to do with the reality of human trafficking. This approach is developed in two directions. On the one hand, it is argued that human trafficking as a violation of human rights is exaggerated, while on the other hand, the criticism is voiced that victims of human trafficking are politically exploited without any real concern for the violation of their human rights.

1. Exaggerating human trafficking as a violation of human rights?

Some critics hold that human trafficking as a human rights violation is exaggerated, for example to legitimize certain political agendas or by NGOs to legitimize their own work. Hörnle, for example, criticizes that the issue here is the self-interest of international organizations and NGOs in popular campaign goals. ${ }^{56}$

52 See in detail Rabe (fn. 49), p. 3 et seq.; H. Rabe/N. Tanis, Menschenhandel als Menschenrechtsverletzung: Strategien und Maßnahmen zur Stärkung der Betroffenenrechte 2013, p. 69 et seq.

53 See Rabe (fn. 49), p. 2.

54 IOM/BM.I Republic of Austria (fn. 50); in detail see Lindner (fn. 5), p. 38 et seq.

55 E. Goździak/N. Bump, Data and Research on Human Trafficking 2008, p. 9.

56 Hörnle (fn. 4), p. 685; Hörnle (fn. 4). p. 120 et seq.; see also Albrecht (fn. 5), p. 38; Lindner (fn. 5), p. 23 et seq. 
a) Low conviction rates - very little human trafficking?

Hörnle questions whether the millions that are spent every year on anti-human trafficking campaigns are used effectively and efficiently. After all, the number of convictions in human trafficking cases in Germany and worldwide is quite low. ${ }^{57}$ Indeed, it is true that due to the limited data available, human trafficking discourses are susceptible to being politically or ideologically appropriated. This is indicated by the arguments that rely on high estimates of the number of victims of human trafficking, where the empirical basis is difficult or even impossible to corroborate. ${ }^{58}$ This has been criticized as "number laundering" 59 or "guestimates" 60 . Nevertheless, the small number of convictions should not suggest that trafficking in human beings is not a serious problem. Rather, the number of convictions says less about the real extent of human trafficking and more about the extent to which the justice system is able to identify and evaluate it. ${ }^{61}$ The issue of how to draw at a more realistic, empirically validated picture of human trafficking remains. It should be noted, however, that in recent years many political and non-governmental actors have made efforts to collect valid data ${ }^{62}$ or to indicate the sources of the data they provide and to illustrate their limited validity. ${ }^{63}$

\section{b) Innocent women and children as ideal victims}

Criticism is also directed towards the focus that is placed on the human trafficking of women and children. It is noted that the focus appears to be on the sexual exploitation of women and girls, while far less information is available on human trafficking at the expense of boys and men and on labour exploitation. ${ }^{64}$ Haverkamp notes that "governments, NGOs, the media, public and research tend to highlight the 'ideal victim' as

57 See Hörnle (fn. 4), p. 677; Hörnle (fn. 4), p. 120.

58 See in detail Lindner (fn. 5), p. 28 et seq.

59 R. Pates/D. Schmidt, Wahrheiten über Opfer: Menschenhandelsdiskurse im Vergleich, in HU Berlin Zentrum für transdisziplinäre Geschlechterstudien (ed.), Der involvierte Blick: Zwangsprostitution und ihre Repräsentation, Bulletin Texte 2008, p. 91 mn. p. 2.

60 See Goodey (fn. 48), p. 425.

61 See Albrecht (fn. 5), p. 41; see IV.1.

62 See IOM/BM.I Republic of Austria (fn. 50); UNODC, Global Report on Trafficking in Persons, 2018, p. 15 et seq.; European Commission/Lancaster University (fn. 41), p. 12 et seq.

63 See e.g. Anti Slavery International, https://www.antislavery.org/slavery-today/human-traffi cking/ (19.12.2019); Terre de Femmes e.V. https://www.frauenrechte.de/en/our-work/focusareas/trafficking-in-women/definitions-and-terminology and https://www.frauenrechte.de/ unsere-arbeit/themen/frauenhandel/begriffsdefinition (19.12.2019); KOK Bundesweiter Koordinierungskreis gegen Menschenhandel e. V. https://www.kok-gegen-menschenhandel.d e/menschenhandel/daten-zahlen-fakten/ (19.12.2019).

64 See Goździak/Bump (fn. 55), p. 9; Lindner (fn. 5), p. 23.

EuCLR Vol. 10, 3/2020 
a young, foreign and innocent woman brutally forced into sex trafficking by an 'ideal trafficker'". 65

In fact, of the investigation figures and estimates presented above, a large proportion of the cases (investigated or estimated) concern trafficking for sexual exploitation. In addition, the percentages of identified or estimated female victims are relatively high. According to the BKA's Federal Situation Report on Trafficking in Human Beings, in $201896.0 \%$ of victims of human trafficking for sexual exploitation or forced prostitution were female, $3.3 \%$ of victims were male, and the sex of the remaining victims was unknown. ${ }^{66}$ According to ILO estimates for 2016, $71 \%$ of victims of modern slavery were female. With regard to the commercial sex industry, it was estimated that $99 \%$ of victims were female; the ratio was $58 \%$ for other sectors. Furthermore, it is thought that $84 \%$ of victims of forced marriage are female. ${ }^{67} \mathrm{It}$ is possible that the disproportionate number, be it determined or estimated, of female victims of crime and human trafficking for sexual exploitation could be due to the notion of the "ideal victim". These stereotyped notions may be leading factors in estimating human trafficking and identifying human trafficking offences, so that human trafficking to the detriment of boys and men, and trafficking for labour exploitation are less likely to be suspected and investigated. Historically, human trafficking of women and children was initially combated as part of the campaign to shut down the slave trade, as shown by various international agreements from 1904, 1910, 1921 and 1933 on combating trafficking in women, girls and children; such agreements, incidentally, initially only concerned themselves with white women and girls (hence the term "white slavery"). ${ }^{68}$ In this respect, too, it must be emphasised that there is a need for a secure and comprehensive empirical footing on which to base appropriate concepts of the phenomenon of human trafficking and the effective combating of it. The guiding principle here should be a critical view of discrimination that takes into account the exploitation of women, men and children as gender- and origin-specific phenomena with their own mechanisms. Haverkamp's proposal that a differentiated view of real victims is needed should therefore be endorsed. This includes taking into account the existence of victims who work voluntarily or later become perpetrators themselves. ${ }^{69}$

65 Haverkamp (fn. 5), p. 68; see for the construction of victims (and perpetrators) of human trafficking for sexual exploitation by means of official acts Pates/Schmidt (fn. 59) and for the example of an NGO Hantzsch (fn. 59).

66 See $B K A$ (fn. 14), p. 7.

67 See $I L O$ (fn. 46), p. 10.

68 Das Abkommen gegen Mädchenhandel von 1904, das Internationale Übereinkommen zu Mädchenhandel von 1910, die Internationale Übereinkunft zu Frauen- und Kinderhandel von 1921 sowie die Internationale Konvention zum Handel mit volljährigen Frauen von 1933. The International Convention for the Suppression of the Traffic in Girls (18 May 1904), the International Convention for the Suppression of the Traffic in Girls (4 May 1910), the International Convention for the Suppression of the Traffic in Women and Children (30 September 1921) and the International Convention for the Suppression of Trade in Adult Women (11 October 1933) In detail see Köbler (fn. 3), p. 29 et seq.

69 See Haverkamp (fn. 5), p. 57, 68 et seq., for the challenges of these studies see p. 62 et seq. 


\section{c) Inappropriate moralization?}

Finally, it is noteworthy that many human trafficking policies and regulations are presented as improperly moralizing. Hörnle, for example, notes that efforts to establish human trafficking as a criminal offence are a prime example of moralizing policies. The efforts of international organizations and non-governmental organizations to combat human trafficking of women and children permit approval to be unanimous, and allows cultural differences between the countries of the United Nations to be bridged. After all, referring to trafficking of women and children activates protective attitudes in traditional, patriarchal societies, and also has an impact in societies that are characterized by normative individualism and whose civil religion is human rights. ${ }^{70} \mathrm{Cam}-$ paigns against human trafficking as "white slavery" are labelled as moral panic. ${ }^{71}$ According to Köbler, the fight against the trafficking of white women and girls at the beginning of the 20th century was actually based less on an acute threat than on social fears and was aimed at restricting the independence of white women wanting to migrate. ${ }^{72}$ Additionally, Markard notes that a racist and anti-Semitic image of a nonwhite Jewish slave trader was formed. ${ }^{73}$ However, the classification of legal processes as moral politics or moral panic does not reveal much about the objective legitimization of the concern to combat human trafficking, insofar as it constitutes a violation of human rights.

Moral policy refers to political discourses that negotiate basic moral values which are presented as indisputable and morally imperative. ${ }^{74}$ In the field of political science, the term is used primarily to examine the specifics of moral-political decision-making processes. In sociology, public and political debates are described as moral panic if they are fuelled by heated moral indignation on the part of a significant part of society which fears that " wrongdoers" threaten the substance of society to such an extent that immediate action must be taken to control and punish this behaviour and avert harm. ${ }^{75}$ Any statement about the quality of the content of the debates is not connected with the classification of a debate as moral-political or moral panic per se, even if such processes are often accompanied by a narrowing of the issue. The labelling of a political process as moral policy or moral panic does not, therefore, devalue it in and of itself; it is rather the negotiated substance and results of the process that must be evaluated in order to assess the quality of its content. The evaluation standard is also the guarantee

70 See Hörnle (fn. 4), p. 677 et seq.; vgl. auch Hörnle (fn. 4), p. 121 et seq.

71 See Haverkamp (fn. 5), p. 53; see also Bergelson (fn. 4), p. 194; N. Markard, Prostitution im internationalen Recht, in: Thiée (Hg.) Menschen Handel, p. 130.

72 See Köhler (fn. 3), p. 32 et seq.; see also Follmar-Otto (fn. 6), p. 31; Markard (fn. 71), p. 130 et seq., p. 141 et seq.

73 See Markard (fn. 71), p. 130.

74 See C. Mooney, The Public Clash of Private Values: The Politics of Morality Policy, in: C. Mooney, The Public Clash of Private Values: The Politics of Morality Policy 2001, p. 3.

75 See E. Goode/N. Ben-Yehuda, Moral Panics: The Social Construction of Deviance, 2. edition 2009 , p. 35. 
of human rights as legal and moral requirements for any legislation. ${ }^{76}$ For human trafficking policies, this means that questions have to be asked as to whether the policies take into account human trafficking phenomena differentiated on a sound empirical basis according to the type and severity of the violation, or whether they make every effort to do so based on the data available to date. Decriminalizing phenomena that are legally classified as human trafficking even though they do not lead to a violation of human rights would be an important step in this direction.

\section{Instrumentalization of trafficking victims for other political purposes?}

The positions just described attempt to counter the risk that human trafficking is dramatized and overly criminalized, even though cases are legally classified as human trafficking despite there being no human rights violation. The counter trend, however, can also be observed in that the legitimate interests of the victims of human rights violations through human trafficking are completely overlooked in favour of other political objectives. ${ }^{77}$ In a study on US and international human trafficking policies, $U b l$, for example, noted that victims of human trafficking have become in an ambivalent manner the focus of governmental, non-governmental and intergovernmental efforts to combat human trafficking: On the one hand, reference to the victim's human rights legitimises the topic of human trafficking being given high priority on political agendas. On the other hand, the discourse has become more focused on security policy, with the victims of human trafficking - rather than the perpetrators - being treated as a security risk. While the discourse in international law defines the elements of the criminal statutes relating to the crime of which the person is the victim, the legal rights of the victim remain either non-binding (Palermo Convention 2000) or only allow minimum standards for residency and accommodation (Council of Europe Convention on Action against Trafficking in Human Beings 2005). ${ }^{78}$ Köbler notes that the fight against human trafficking must not itself be allowed to become a violation of human rights. ${ }^{79}$

These positions are based on the assumption that the human rights of victims of human trafficking are insufficiently guaranteed by the law because other policy goals, such as the fight against human trafficking through criminal law or the fight against illegal migration, are ultimately at the centre of interest. Legal discourses are then re-

76 See A. Schmidt, Zum Zusammenhang von Recht, Moral, Moralpolitik und Moralpanik am Beispiel der Reform des Sexualstrafrechts, Zeitschrift für Rechtssoziologie (ZfRsoz) 2018, p. 247 et seq., p. 254 et seq.; see also Renzikowski (fn. 3), p. 77, calling human rights a moral requirement for the legislator. However, human rights are legally enshrined in various international conventions and in catalogues of fundamental rights, so that they are not only morally but also legally binding.

77 See e.g. Köhler (fn. 3), p. 53 et seq.

78 See $\operatorname{Ubl}($ fn. 3), p. 209 et seq., esp. p. 213 et seq.

79 See Köhler (fn. 3), p. 62. 
duced to criminal law enforcement and the issue of human trafficking as a migration problem. ${ }^{80}$

\section{a) Reducing legal discourse to criminal proceedings}

When considering European and national legal discourse in Germany, it is clear that although the primary concern is to guarantee basic and human rights for the victims of human trafficking, these are not always at the centre of measures to combat human trafficking.

Art. 8 of Directive 2011/36/EU requires that Member States implement the necessary measures to ensure that competent national authorities have the power to decide not to prosecute or impose penalties on victims of trafficking in human beings for their involvement in criminal activities which they have been compelled to commit as a direct consequence of their being trafficked. This corresponds to Article 26 of the Council of Europe Convention on Action against Trafficking in Human Beings, which has not been adequately implemented in Germany. ${ }^{81}$ Whilst the public prosecutor's office may, under $\$ 154 c$, Subsection 2, StPO, refrain from prosecuting an offence committed by the victim of human trafficking if the offence was due to human trafficking and the victim reported the trafficking, the decision to do so is at the discretion of the public prosecutor's office, and the courts cannot decide this issue. The victims cannot predict whether or not they will be exempted from punishment if they report the crime. ${ }^{82}$ The perpetrators can, therefore, continue to threaten the victims, telling them that they themselves might be criminally prosecuted if they report a crime. An important condition that makes human trafficking possible - the possibility of the perpetrators blackmailing the victim - remains. ${ }^{83}$

According to Article 14 (1) of the Council of Europe Convention on Action against Trafficking in Human Beings, renewable residence permits are to be issued to the victim either if the competent authority considers that their stay is necessary owing to their personal situation or if their stay is necessary for the purpose of their cooperation with the competent authorities in investigation or criminal proceedings. The residence permit is to be granted if either or both conditions are met. A purely humanitarian right of residence, as repeatedly called for by (human rights) experts ${ }^{84}$, is thus not guar-

80 Köbler (fn. 3), p. 53 ff. provides an overview of the different approaches to combating human trafficking; the criminal law, the migration, the gender-specific and the human rights approaches.

81 See Article 4 section 5 Nr 4 Gesetz zur Verbesserung der Bekämpfung des Menschenhandels und zur Änderung des Bundeszentralregistergesetzes sowie des Achten Buches Sozialgesetzbuch vom 11. Oktober 2016, BGBl I 2226.

82 See Renzikowski (fn. 3), p. 85.

83 See Renzikowski (fn. 3), p. 86; Lindner (fn. 5), p. 247.

84 See Deutsches Institut für Menschenrechte (DIMR), Schriftliche Stellungnahme des Deutschen Instituts für Menschen zur öffentlichen Anhörung des Ausschusses für Menschenrechte und humanitäre Hilfe "Menschenhandel und Zwangsprostitution in Europa" vom 21.05.2014, p. 4; Deutscher Juristinnenbund e.V., Stellungnahme zur Reform der 
anteed to victims of human trafficking. According to Art. 8 (1), (2)I of Directive 2004/81/EC ${ }^{85}$, a temporary residence permit for third-country nationals as victims of human trafficking is to be granted only if the prolongation of their stay presents opportunities for investigation or judicial proceedings, (a) if the victim has clearly expressed a clear intention to cooperate and (b) if they have severed all relations with suspected perpetrators of acts of trafficking (c).

German law ties residence permits for third-country nationals who are victims of human trafficking closely to criminal prosecution. As a result, $\mathbb{} 25$ IV a of the Residence Act stipulates that the granting of a residence permit on humanitarian grounds is subject to the condition that (1) the presence of the victim in the federal territory is deemed appropriate in connection with criminal proceedings for trafficking in human beings, that (2) he has broken off all contact with the persons accused and (3) has declared his willingness to testify as a witness in the criminal proceedings. The residence permit should be extended if humanitarian or personal reasons or public interests require it. Thus, the victim must be prepared to cooperate with the public prosecutor's office up to the point of testifying at trial, without being sure that cooperation in the trial is deemed appropriate.

If victims of human trafficking are victims of a violation of human rights, they have a right of residence on grounds of the violation of their human rights. Human rights apply unconditionally. Granting victims these rights must, therefore, not be made conditional on them earning a residence permit through conduct that is desirable for the state; ${ }^{86}$ in this respect, they do not have a contractual relationship with the state. ${ }^{87}$ In this context, the provisions for the residence permits disregard the victim's human rights if they have been violated by trafficking in human beings by focusing on ensuring prosecution as a state interest pursued at the expense of trafficking victims. This is not legitimate also because effective criminal prosecutions are not only intended to safeguard the interests of the state in combating crime, but also to guarantee the human rights of victims of human trafficking. The ECtHR, accordingly, derives the obligation of states to prosecute human trafficking from Article 4 ECHR, i.e. a guarantee of human rights..$^{88}$

\section{b) Reducing legal discourse to human trafficking as a migration problem}

The above-mentioned examples of regulations show not only that combating human trafficking is reduced to state interests in criminal prosecution, but also that it is reduced to national interests in combating illegal migration. Academic literature often portrays human trafficking as a migration problem as well, and associates it with illegal

Strafvorschriften des Menschenhandels, Verbesserung des Schutzes der Opfer von Menschenhandel und Regulierung der Prostitution, p. 16 et seq.; Rabe/Tanis (fn. 52), p. 29 et seq.

85 Of 29 April 2004, L 261/19 of 6.8.2004.

86 See Renzikowski (fn. 3), p. 86.

87 See Lindner (fn. 5), p. 247.

88 See ECHR, Rantsev v. Cyprus and Russia (fn. 6), margin no 288. 
smuggling of foreigners into countries. Hörnle, for example, regards part of the phenomenon of human trafficking as a problem of migration, including illegal migration. More precisely, she assumes that no serious violation of fundamental rights of human trafficking victims occurs if people leave their own social environment as a result or their own volition and are willing to endure exploitation because of their precarious living conditions. Migrants who do not meet the criteria for legal labour migration are often dependent on informal migrant networks that enable illegal entry. ${ }^{89}$

Initially, a strong case can be made for a systematic separation between human trafficking and migrant smuggling. Human trafficking typically takes place against the victim's will, and acts of human trafficking do not necessarily have to be carried out across borders. Trafficking is directed against the individual rights of the victim. On the other hand, smuggling of human beings is cross-border in nature and can take place with the consent of the smuggled person and for the mutual benefit of both parties. Smuggling does not violate individual rights, but rather the sovereignty of the state over its borders. ${ }^{90}$ Thanks to this systematic separation, serious human rights violations by human trafficking can be recorded as such, even if the entry of the trafficking victim into the country was illegal. The trafficked person whose human rights have been violated cannot simply be treated as a person who has entered the country illegally, but, on grounds of the human rights violation, requires first and foremost the protection of the state. Human rights are, as noted earlier, unconditional. For example, it is important to avoid the situation where victims of human trafficking are identified as having entered the country illegally and are deported without it even being established that they are victims of human trafficking. ${ }^{91}$

However, it should also be remembered that systematic separation only covers phenomena of a typified nature, i.e. there is also human trafficking with the consent of the trafficked person and smuggling against the will of the smuggled person..$^{92}$ In the nursing care case described above, the exploited person agreed to be trafficked. A person who is illegally moved to another country against their will for the purpose of exploitation is smuggled against their will. Smugglers can thus also violate the human rights of the people they smuggle by putting them in great danger, deceiving them about the true circumstances of the journey or taking advantage of a particular helplessness, as often happens in smuggling across the Mediterranean. ${ }^{93}$ Human trafficking phenomena are often apparently linked to the particular vulnerability of people who,

89 See Hörnle (fn. 4), p. 675 et seq.; see also Hörnle (fn. 4), p. et seq.

90 See Köhler (fn. 3), p. 44 et seq.; Lindner (fn. 5), p. 19 et seq.; Anti Slavery International, https://www.antislavery.org/slavery-today/human-trafficking/ (19.12.2019); Follmar-Otto (fn. 6), p. 17 f.; UNODC, http://www.unodc.org/unodc/en/human-trafficking/faqs.html\#H ow_is_human_trafficking_different_to_migrant_smuggling (20.12.2019).

91 See Follmar-Otto (fn. 6), p. 18.

92 See for the typisation of human trafficking victims and smuggled persons E. Pirjatanniemi, Victims of Trafficking in a Migration Discourse, in: Haverkamp / Herlin-Karnell / Lernestedt (eds.) What is Wrong with Human Trafficking?, p. 93 et seq.

93 See Lindner (fn. 5), p. 19; see also Pirjatanniemi (fn. 92), p. 86; Follmar-Otto (fn. 6), p. 17 et seq. and for the transition between human trafficking and smuggling and the reverse $U N$ - 
in the context of globalization and the gap between rich and poor, want to immigrate to rich countries, while the rich countries adopt a restrictive immigration policy. $\mathrm{Hu}-$ man trafficking and migration policies must, therefore, take a comprehensive and differentiated view of these issues. ${ }^{94}$

\section{Conclusion}

Human trafficking phenomena are diverse and still empirically under-researched. This leaves the debates about preventing and combating human trafficking vulnerable to political and ideological bias. The diversity of the phenomena must be considered in a differentiated manner in debates on and measures taken against human trafficking. An important differentiation factor for typifying cases and assessing the effectiveness and appropriateness of anti-trafficking measures is whether human rights are violated by the human trafficking. After all, guaranteeing the unconditional human rights of trafficked persons should be the primary normative objective of international, supranational and national interventions to combat human trafficking. This means that neither should all phenomena that have so far been classified in legal terms as human trafficking be inflated to become human rights violations, nor should human rights violations caused by human trafficking be trivialized and subordinated to the interests of security and migration policy.

ODOC, http://www.unodc.org/unode/en/human-trafficking/faqs.html\#How_is_human_tr afficking_different_to_migrant_smuggling (20.12.2019).

94 See Follmar-Otto (fn. 6), p. 23, 43 et seq.; Munro (fn. 29), p. 366 et seq., 378 f. and also Beck/ Tassis, in this issue. 